\title{
MYOPIA AND ITS PREVENTION USING THERAPEUTIC PHYSICAL TRAINING IN SCHOOLCHILDREN
}

\author{
Olha Voronkova \\ Dr. Med., Professor, Oles Honchar Dnipro National University, Ukraine \\ e-mail: voronkova.olga.04@gmail.com,orcid.org/0000-0003-3380-6871
}

Anna Lemberg

Ph.D., Assistant Professor, Oles Honchar Dnipro National University, Ukraine e-mail: annalembox@gmail.com,orcid.org/0000-0001-6200-5921

\section{Tetyana Shevchenko}

Dr. Sci. Biol., Professor, Oles Honchar Dnipro National University, Ukraine e-mail: dnushevchenkot@gmail.com,orcid.org/0000-0002-0947-0960

\section{Maryna Scherbinina}

Dr. Sci. Biol., Professor, Oles Honchar Dnipro National University, Ukraine e-mail: scherbinina@ua.fm,orcid.org/0000-0002-2358-5406

\section{Summary}

Vision is the one of the most significant function of human body. Many factors can influence on health of eyes and lead to the problem with vision. The aim of the work was to analyze information on myopia in school-age children and to make a set of training exercises for its prevention in them. In article present an overview of problem of myopia in school-age children, it causes and risk factors, possibilities of it prevention by use of different methods, including therapeutic physical training. Proposed complex of exercises designed for children of middle and high school. It includes 13 exercises for $30 \mathrm{~min}$ of training twice a day outdoor or in gymnasium. Exercises can be done anone or in pairs. Complex is recommended to children with myopia and children, which have normal vision, for the prophylaxis of impairment of vision. Complex can be used from childhood to to achieve the maximum effect, keep in mind the significant load on the visual analyzer of a modern child.

Keywords: vision impairments, causes, treatment, prophylaxix, complex of physical exercises, children.

DOI: https://doi.org/10.23856/4534

\section{Introduction}

Vision is one of the main function for obtaining information in human. Vision is an important factor in human orientation, which is absolutely necessary throughout life. Vision is also important for success in school. Problems and vision in students limit the ability to learn in all groups of subjects, which may ultimately affect success in life (Orlova \& Kostetska, 2014; Burnett et al., 2018).

Vision problems are quite common among school-age children, and today this problem is becoming more widespread due to the digitalization of society and the transfer of much of children's contacts to social networks accessible from smartphones and tablets, as well as the spread of computer games available via the Internet (Lee et al., 2019). 
According to the Center for Medical Statistics of the Ministry of Health of Ukraine, over the past 10 years, the number of children with pathology of the eyes has increased significantly. Every year, 840,000 cases of ophthalmic diseases are registered in children in Ukraine. There are 10.7 thousand blind and partially vision children in Ukraine and their number grows by 1 thousand every year. According to the results of annual preventive examinations of students, the frequency of detection of reduced visual acuity among students during schooling increases by 3-5 times and at the end of study in school is 30\% (Kostetska, 2012; Guidelines, 2014).

The most common vision problems in children are more often myopia and less often hyperopia. These common vision problems are easily corrected with glasses or contact lenses, however, the choice of glasses or lenses should be based solely on the expert opinion of a doctor (Rykov et al., 2019).

It is important to note that a visit to an ophthalmologist should also take place for prophylactic purposes, ie it is desirable even in the absence of obvious signs of vision problems. According to American guidelines, children must undergo an eye examination no later than 6 months, then again at the age of 3 years, and immediately before school. School-age children need to be examined every two years from the start of school, even if they do not have vision problems. If there are problems, the survey should be conducted every year (Guidelines, 2014; Chang et al., 2017).

In 2019, Ukraine has developed its own standard of survey "Comprehensive examination of the eye and vision: clinical guidelines based on evidence", which contains a detailed description of the survey procedure, including for children (Rykov et al., 2019).

Frequent survey by an ophthalmologist are important for children, because during the school years the prescription of a child's glasses can change quite often.

In addition, in visual lesions it is very important to avoid complications that can be provoked by impaired eye hygiene, excessive physical and mental stress, etc. (Kostetska, 2012; Orlova \& Kostetska, 2014). For a number of cases, a special regime of physical activity is developed to prevent visual problems and preventive exercises are developed to correct it (Wu et al., 2013; Chang et al., 2017; Burnett et al., 2018).

For the prevention of eye disease in schoolchildren, a system of special training exercises designed to prevent eye fatigue can be used. These exircises are done twice or thrice a day and during lessons involving high visual stress, such as computer science (preferably under the supervision of a teacher) (Wu et al., 2013; Chang et al., 2017; Burnett et al., 2018).

Thus, there is an urgent need to develop tools for early detection and effective vision correction in school-age children, which will ensure their effective learning and safe leisure activities (Guidelines, 2014; Burnett et al., 2018; Rykov et al., 2019).

The aim of the work is to investigate the effectiveness of physical culture in the prevention of visual impairments and myopia among children of middle and high school age.

The aim of the work was to analyze information on myopia in school-age children and to make a set of training exercises for its prevention in them.

\section{Myopia and its causes}

During the growth of the eyeball changes its shape, convexity of the cornea and lens and up to 9-12 years, the relationship between the refractive power (optical component) and the length of the axis (anatomical component). If in the process of eye formation the correspondence between optical and anatomical components is established, then normal (emetropic) refraction develops (Wu et al., 2013). 
However, there are cases of non-compliance of refraction with the norm, among which we can distinguish myopia.

Myopia (Greek "myops" - "squint"), or myopia, is one of the most common visual lesions. Short-sighted people close their eyes to "sharpen" and see something in the distance (Kyzymenko \& Snyadanko, 2009; Tsybulska, 2019).

Myopia is a defect of vision in which objects are clearly visible nearby and poorly (in the form of a blurred image) - in the distance. More than $30 \%$ of all inhabitants of our planet suffer from myopia (in some countries, for example, in Japan, this indicator exceeds even 60\%).

In a person with good eye vision, the image is focused on the retina (as it should be). But with myopia, the focus is in front of the retina, which leads to blurred vision. The reason may be an elongation of the eyeball or a change in the refractive power of its optical system (cornea or lens). Many people have both of these disorders at once (Domashenko, 2008; Orlova $\&$ Kostetska, 2014). Thus, myopia is a refraction during which parallel rays coming from distant objects intersect in front of the retina and do not reach it. This refraction may be due to the longitudinal axis of the eye being too long (more than 22.5-23.0 $\mathrm{mm}$ ) or greater than the normal refractive power of the eye. In myopia, glasses with scattering biconcave lenses are prescribed, which reduce the refraction of rays and focus the image of the object on the retina (Jonas et al., 2016; Tsybulska \& Pashkova, 2018).

The ability of the eye to distinguish the smallest distance between two points, which is achieved when there is one unexcited cone between two excited cones, is called visual acuity. A measure of visual acuity is the angle formed between the rays going from two points of the object to the eye. The smaller this angle, the higher the visual acuity. Normal visual acuity is considered when this angle is equal to one angular minute (Li et al., 2015; Tsybulska \& Pashkova, 2018; Tsybulska, 2019).

Visual acuity is considered highest when the image hits the area of the central fovea or macula. To determine visual acuity use tables of letters, numbers, broken rings and drawings of different sizes (for preschoolers). An indicator of visual acuity for each eye is a row of the smallest objects, which was identified without errors by the subject. To the right of the line is the visual acuity - from 0.1 to 2.0 units. Determine visual acuity for each eye separately, at a distance of $5 \mathrm{~m}$ from the table, in intense light.

Visual acuity in children with normal refraction increases with age. Thus, in 4-5 years it is on average $0.80 \%$, in $5-6$ years $-0.86 \%$, in $7-8$ years $-0.91 \%$. At the age of 10 to 15 years, visual acuity increases from $0.98 \%$ to $1.15 \%$.

During childhood, this type of refraction, such as hyperopia, predominates. The frequency of normal refraction and myopia is very low. In later age periods, hyperopia occurs less frequently, and emetropia and myopia more often. During schooling, the number of shortsighted children increases 5 times from school entry to graduation. Lack of light significantly affects the formation and progression of visual lesions in school-age children. Visual acuity and resistance to clear vision in schoolchildren are greater at the beginning of lessons and weaken by the end of them. The attenuation is sharper the lower the light level. An important factor that leads to a decrease in visual acuity, development and progression of myopia in students during school (even with sufficient levels of lighting in classrooms and endurance within the normative limits of other parameters of light factors) is the workload, its duration during the day (French et al., 2013; Holden et al., 2016).

Significantly expressed in children and adolescents is the relationship between the frequency of myopic refraction, the state of phosphorus-calcium metabolism and the duration of daily exposure to ultraviolet radiation. Phosphorus-calcium metabolism is disturbed in children 
who have little or no walks at noon, when the intensity of ultraviolet radiation is high enough. This results in changes in the tone of the eye muscles. Weakness of these muscles at high visual load and insufficient light causes the development of refraction anomalies and their progression (Ip et al., 2008; Duhina, 2016).

The first signs of myopia may be a schoolchildren's complaint that he has begun to have difficulty seeing what is written on the board. When he reads, he raises the book close to his eyes, tilts his head sharply while writing, squints his eyes while examining objects.

Myopia usually develops under the influence of long and chaotic work at close range without following the hygienic norms of reading or writing. Rickets, tuberculosis, rheumatism and other common diseases can create a breeding ground for the development of myopia (Ip et al., 2008).

Myopic refraction from $3.25 \mathrm{D}$ and above at visual acuity with correction from 0.5 to 0.9 is the basis for enrollment of children and adolescents in III and IV health groups, ie patients. In case of any visual deviations in children and adolescents (except catheter vision, acuity, light perception, field of vision and other changes) they need close attention of an ophthalmologist and strict adherence to all his prescriptions at school and at home (Tsybulska \& Pashkova, 2018; Tsybulska, 2019). Given the degree of loss of visual acuity (measured in diopters) distinguish myopia:

- weak - less than 3.0 diopters (determined in about $82 \%$ of persons). It is characterized by an increase in eye length by $1-1.5 \mathrm{~mm}$. With such a violation of refraction, a person sees the outlines of distant objects a little blurry;

- average - 3.25-6.0 diopters (determined in about $12 \%$ of persons). It is characterized by elongation of the eyeball by 1-3 $\mathrm{mm}$. At this stage, the membranes and vessels of the eye undergo changes, stretch and thin. Vision in the distance is reduced, and nearby a person sees clearly and distinctly at a distance of only $20-30 \mathrm{~cm}$;

- high - more than 6.0 diopters (determined in about $6 \%$ of subjects). It is characterized by an increase in the length of the eyeball by $3 \mathrm{~mm}$ or more. This threatens a significant thinning of the retina and vascular membranes of the eye and a significant reduction in visual acuity up to $30 \mathrm{D}$ and more (Tsybulska, 2019).

With mild to moderate myopia, hypermetropia, astigmatism, the doctor should examine schoolchildren once a year, and with high myopia (more than $6.0 \mathrm{D}$ ) twice.

According to various criteria, myopia is divided into several types. If it is associated with congenital anomalies of the eyeball, it is congenital myopia. Rare - in $2 \%$ of cases, the child is born with an enlarged (compared to normal) eyeball. In the vast majority of cases, myopia appears at school age. Defects in the synthesis of connective tissue protein (collagen), necessary for the structure of the sclera, are inherited. Weakening of the scleral tissue leads to an increase in the size of the eyeball and, as a consequence, to the development of myopia. If both parents are myopic, the risk of developing myopia in a child is $80 \%$, if one $-40 \%$. In other cases, it is an acquired myopia (Cooper \& Tkatchenko, 2018; Tsybulska, 2019).

If vision deteriorates by more than one diopter per year, it is progressive myopia that requires special attention and treatment. Myopia progresses most intensely in children during the school years, when pressure on eyes are particularly high.

Myopia can be true, ie caused by the structure of the eye, and false - when vision deteriorates due to accommodation disorders, and anatomical changes (foe example, elongation of the eyeball) does not occur (Li et al., 2015; Holden et al., 2016).

In the prevention of myopia among schoolchildren the great importance belong to: 
- the distance from the eyes to the top and bottom line on the page of the book or notebook. Different distances to these lines cause fatigue, because the shape of the lens must change so that the text can be clearly seen (Kostetska, 2012). The solution can be realized through the use of a desk with a tilt of the table cover. This facilitates the work of the schoolchildren, because when the book is placed on an inclined plane, the top and bottom lines of the page are approximately the same distance from the eyes (Datsenko et al., 2001);

- rules of personal hygiene: frequent washing of hands with soap, frequent change of towels for personal use, handkerchiefs, etc. helps to prevent infectious eye diseases, the severe consequences of which are visual impairments up to complete loss;

- nutrition is essential, the degree of its balance in terms of nutrients and especially vitamins, especially vitamins $\mathrm{A}, \mathrm{B}_{2}$ and $\mathrm{B}_{6}, \mathrm{C}$ (Guidelines, 2014; Colenbrander, 2018);

- prevention of eye injuries in schoolchildren has a special place among children of all ages. It includes strict adherence to safety rules in physical education lessons, in labor lessons, during experiments in chemistry, physics and biology lessons;

- the teacher should also monitor the health of children by monitoring their placement in the classroom in accordance with medical recomendations, as well as controlling the distance of children from the table surface. In order to prevent eye disease in students, the teacher must master a system of special training exercises and teach it to children. They are performed 2-3 times during the school day and during tasks related to high visual stress, such as computer science (preferably under the supervision of a teacher) (Wu et al., 2013; Chang et al., 2017; Colenbrander, 2018).

- light regime in educational premises. The desk or desk should be placed so that natural light falls on the child's left, if he is not left-handed. In the absence of daylight, artificial lighting should be used. Visual acuity and stability of clear vision in schoolchildren are greater at the beginning of lessons and weaken by the end of them. The attenuation is sharper the lower the light level. Lack of light significantly affects the formation and progression of visual lesions in school-age children. This should be taken into account when planning training facilities and the location of equipment in them (Datsenko et al., 2001);

- posture also helps to preserve vision. To prevent postural disorders can include sports or dancing and limiting time for sedentary work or leisure on the computer or TV (Datsenko et al., 2001; Wu et al., 2013; Colenbrander, 2018);

- quality of textbooks and other printed products. When purchasing such goods, it is mandatory to require documents on product certification and hygienic conclusion on its compliance, if such information is not indicated on the product itself (Datsenko et al., 2001).

The task of any correction of myopia is to weaken the refractive power of the eye so that the image falls on the central area of the retina. To date, there are more than 20 ways to correct myopia (Tsybulska, 2019). Treatment of myopia in most cases aims at conservative approaches:

- correction of myopia by glasses. After the survey, lenses are prescribed taking into account the degree of myopia and diopters. With a low degree, the glasses may not be intended for permanent use, but from time to time if clearly needed.

- contact correction - treatment of myopia with contact lenses. These are convenient tools that can correct even the highest myopia (minus 15 - minus 22 diopters), while quite easy to use.

- gymnastics for the eyes. A series of gymnastic exercises for the eyes will help to normalize vision in low myopia, make the eye muscles more stable and invulnerable to stress.

- medications. Sometimes special eye drops are prescribed, which also reduce tension and relax the eye muscles. 
- proper nutrition, which contains all the necessary vitamins and trace elements, improves the condition of the eye organs and protects them from the progression of myopia.

- laser correction. A very common way of correction of myopia. During the intervention, the cornea is corrected, due to which vision is restored even with a very high degree of myopia (Ruban, 2016; Moiseyenko et al., 2018; Dmytriv et al., 2019).

\section{Therapeutic exercise against myopia}

Therapeutic physical training (TPT) has a separate area, in which complexes of physical exercises for the eyes have been developed to help prevent the development of visual impairments and can act as an element of correction of such problems.

The essence of TPT is that these exercises:

- ensure the preservation of the health of the system of vision;

- allow to use the acquired skills independently in extracurricular activities and later in life (Milyukova \& Yevdokimova, 2003).

The principles of TPT are aimed at strengthening physiological and psychological health, namely:

- the principle of motor activity;

- the principle of health regime;

- the principle of implementation of effective hardening;

- the principle of psychological comfort;

- the principle of reliance on the individual characteristics and abilities of the child (taking into account the leading temperament) (Milyukova \& Yevdokimova, 2003; Duhina, 2016; Ruban, 2016).

In addition, eye exercises are combined with other areas of therapeutic exercise, which adds the principle of forming the correct posture and skills of rational breathing.

In general, for the prevention of problems of vision and their correction should be used a comprehensive approach, including: the mode of dynamic poses, a system of sensor-search motor-coordinator training, open classroom space, environmentally friendly printed materials, multicolored supports on cruciform handles, universal symbols, massage mats for feet, desks, etc. These techniques in the complex are quite expensive, so it is impossible to organize them in every school, however, the simplest actions (physical exercises for the eyes) is accessible to all and requires only time (Duhina, 2016). the body.

Exercise has a tonic (stimulating), trophic (compensatory) and normalizing effect on

The tonic effect of exercise is expressed primarily in the stimulation of motor-visceral reflexes, increased afferent impulses of proprioceptors and stimulates cellular metabolism in the neurons of the central link of the motor analyzer, resulting in increased trophic effects of the central nervous system on muscles and internal organs, ie for the whole organism (Milyukova \& Yevdokimova, 2003).

The effect of regular exercise is also on the cardiovascular system, which indirectly affects the visual analyzer by improving its blood supply. Thus, exercise is an effective factor in improving the general condition of the body, enhancing the adaptation of all systems to increasing physical activity and increasing their functional abilities.

The body's training leads to a reduction or disappearance of the subjective manifestations of various diseases, including a reduction in the load on the visual analyzer, significantly improves the physical condition and efficiency of the person. 
Among other methods of stimulating or tonic action, physical exercises have certain advantages, which are their physiological and adequacy, universality (a wide range of physical exercises), the absence of negative side effects (with the correct dosage and rational method of training), the possibility of long-term use, which practically has no restrictions, passing from medical to preventive and general health (Milyukova \& Yevdokimova, 2003; Kadochnikova \& Khorkova, 2017).

The trophic effect of exercise is the basis of one of the mechanisms of physiological regulation of tissue metabolism through trophic reflexes. This function is performed by various parts of the central nervous system, including the cerebral cortex and hypothalamus. The effect is carried out on the relevant parts of the visual analyzer, located in the human brain.

With a lack of tonic and stimulating effects on the part of the central nervous system, the tone of skeletal muscles and the frequency of proprioceptive impulses decreases, which, in turn, affects nerve trophism. This impulse, which is amplified during exercise, stimulates nerve trophism and restores the normal relationship between the musculoskeletal system and physiological systems of the body (respiratory, cardiovascular, etc.). The functional state of the nerve centers that regulate the work of various organs changes. This adjustment is maintained and intensified, contributing to the trophism and performance of muscles, and not only skeletal but also internal organs, especially the myocardium. The positive effect of training has been noted for other muscles, in particular, the known positive effect of physical activity on visual acuity (Formenti et al., 2019; Tymchyk, 2019).

Any physical exercise contributes to the overall strengthening of the body and activation of its function, including increasing the efficiency of the ciliary muscle and strengthening the sclera of the eye. Exercises also have a restorative effect that maintains a certain level of visual acuity, ie have a preventive effect on the visual organ.

Exercises used in case of lesions of eyes solve the following tasks:

- general strengthening of an organism;

- activation of the functions of the respiratory and cardiovascular systems;

- strengthening of the musculoskeletal system;

- improving blood circulation in the tissues of the eye;

- improving the activity of the eye muscles, especially the ciliary muscle;

- strengthening of the sclera;

- increasing the level of physical development and physical fitness;

- prevention and correction of posture changes;

- prevention of progression of myopia (Milyukova \& Yevdokimova, 2003; Kadochnikova \& Khorkova, 2017).

\section{Complexes of exercises for schoolchildren to correct myopia}

Among all the types of ocular pathology, exercise is used only for glaucoma and myopia. Special exercises are shown to all persons who have progressive acquired and uncomplicated retinal detachment of any degree of myopia. Age is not the limit, but the use of special exercises is mandatory. The earlier special exercises are prescribed for myopia and the lower the degree of myopia, the higher the effectiveness of the method (Milyukova \& Yevdokimova, 2003; Guidelines, 2014). The prescribed exercises should be used systematically. This running, swimming, walking on skis of moderate intensity in combination with special accommodation training significantly increases the level of endurance and has a positive effect on the accommodation of the eyes (He et al., 2015; Formenti et al., 2019). 
Within the daily use, general physical exercises are effective, which are used in combination with special exercises for the ciliary muscle, which improve accommodation and have a positive effect on the functions of the myopic eye (Rose et al., 2008; Wu et al., 2013; Ruban, 2016).

It is better to do special exercises for the eyes at the same time as general breathing exercises, corrective exercises, as well as exercises for the neck and back muscles. They are usually included in a set of exercises to improve the functionality of the cardiovascular and respiratory systems, as well as to strengthen the muscular corset, neck and back muscles, weakened by incorrect posture during visual work (sharply tilted head, stooped back). In a set of preventive measures outside the person during work is of great importance (Milyukova \& Yevdokimova, 2003; Guidelines, 2014).

An additional set of exercises was used in an additional lesson (30 $\mathrm{min}$ ) for boys and girls who had signs of myopia, for the prevention and correction of myopia are presented in table. Complex based on recommendation of (Milyukova \& Yevdokimova, 2003; Guidelines, 2014; Kang et al., 2016; Chang et al., 2017; Kadochnikova \& Khorkova, 2017; Colenbrander, 2018).

Table 1

A set of exercises to strengthen the ciliary muscle in boys and girls with signs of myopia

\begin{tabular}{|c|c|c|}
\hline Exercises: Starting position & Procedure of movements & Repeat \\
\hline 1 & 2 & 3 \\
\hline $\begin{array}{l}\text { Standing, legs apart, arms in front of } \\
\text { chest with ball }\end{array}$ & $\begin{array}{l}\text { Throwing the ball from the partner's chest (across } \\
\text { the floor or air), standing } 5-7 \mathrm{~m} \text { (watch the ball } \\
\text { with your eyes) }\end{array}$ & $12-15$ \\
\hline $\begin{array}{l}\text { Standing, legs apart, hands behind } \\
\text { his head with the ball }\end{array}$ & $\begin{array}{l}\text { Throwing the ball to a partner standing } 5-7 \mathrm{~m} \\
\text { (watch the ball with your eyes) }\end{array}$ & $10-12$ \\
\hline $\begin{array}{l}\text { Standing, legs apart, one hand with } \\
\text { the ball on his shoulder, the other } \\
\text { holding the ball on top }\end{array}$ & $\begin{array}{l}\text { Throwing the ball to a partner standing } 5-7 \mathrm{~m} \\
\text { with one hand (watch the ball with your eyes). } \\
\text { Alternate performance with left and right hands }\end{array}$ & $7-10$ \\
\hline $\begin{array}{l}\text { Standing, legs apart, arms } \\
\text { outstretched }\end{array}$ & $\begin{array}{l}\text { The ball is thrown up and caught, watching its } \\
\text { movement }\end{array}$ & $7-10$ \\
\hline $\begin{array}{l}\text { Standing, legs apart, arms } \\
\text { outstretched }\end{array}$ & $\begin{array}{l}\text { The ball is forcibly thrown down and caught after } \\
\text { the rebound, watching its movement }\end{array}$ & $6-7$ \\
\hline $\begin{array}{l}\text { Standing, legs apart, arm with ball } \\
\text { extended forward }\end{array}$ & $\begin{array}{l}\text { The ball is thrown and caught with one hand } \\
\text { (possibly two), watching it. Alternately right and } \\
\text { left hands }\end{array}$ & $6-8$ \\
\hline $\begin{array}{l}\text { Standing, legs apart, ball in one } \\
\text { hand, distance from the wall 5-8 m }\end{array}$ & $\begin{array}{l}\text { The ball is thrown into the wall and caught after } \\
\text { the rebound, watching him with his eyes. Alter- } \\
\text { nately right and left hands }\end{array}$ & $6-8$ \\
\hline $\begin{array}{l}\text { Standing, legs apart, ball in one } \\
\text { hand, distance from the wall } 5-8 \mathrm{~m}\end{array}$ & $\begin{array}{l}\text { The ball is thrown across the floor to bounce off } \\
\text { the wall, and caught after the bounce, watching } \\
\text { it with the naked eye. Alternately right and left } \\
\text { hands }\end{array}$ & $6-8$ \\
\hline $\begin{array}{l}\text { Standing, legs apart, ball in one } \\
\text { hand, distance from the target } \\
\text { (basket) } 5-8 \mathrm{~m}\end{array}$ & $\begin{array}{l}\text { The ball is thrown at the target, watching it with } \\
\text { his eyes. Alternately right and left hands }\end{array}$ & $6-8$ \\
\hline $\begin{array}{l}\text { Standing, the ball lies on the floor, } \\
\text { the distance from the wall is } 5-8 \mathrm{~m}\end{array}$ & $\begin{array}{l}\text { Alternate kicking of the ball to the wall with } \\
\text { tracking of the movement of the ball and reflec- } \\
\text { tion in the wall after return }\end{array}$ & $5 \mathrm{~min}$ \\
\hline
\end{tabular}


Table 1 (Continued)

\begin{tabular}{|l|l|c|}
\hline \multicolumn{1}{|c|}{1} & \multicolumn{1}{|c|}{2} & \multicolumn{1}{|c|}{3} \\
\hline $\begin{array}{l}\text { Standing, the ball lies on the floor, } \\
\text { the distance from the partner is } \\
5-8 \mathrm{~m}\end{array}$ & $\begin{array}{l}\text { Alternate kicking of the ball to the partner with } \\
\text { tracking the movement of the ball }\end{array}$ & $5 \mathrm{~min}$ \\
\hline Standing, cane in one hand & $\begin{array}{l}\text { Lifting through the side of the cane with tracking } \\
\text { its end with the eyes without turning the head and } \\
\text { transferring to the other hand at the highest point, } \\
\text { followed by lowering through the side and track- } \\
\text { ing its end with the eyes without turning the head }\end{array}$ & 20 \\
\hline $\begin{array}{l}\text { Standing, legs apart, hands in a circle, } \\
\text { distance from the partner 5-8 m }\end{array}$ & $\begin{array}{l}\text { Throwing the circle forward to the partner with } \\
\text { giving him back rotation, watching the movement }\end{array}$ & $10-12$ \\
\hline
\end{tabular}

If it is impossible to perform certain gymnastic tasks from the list in the table (for example, exercises with a ball at home), it can be increase the time / number of exercises to perform other actions from the list or use other exercises to avoid monotony (Milyukova \&Yevdokimova, 2003; Guidelines, 2014).

\section{Conclusions}

It is known that children who do not systematically undergo a vision survey often do not receive the necessary timely solution to the problem. Two studies published by the American Academy of Ophthalmology found that 40 to $67 \%$ of children who do not undergo preventive vision testing do not receive the recommended follow-up care. One of the reasons for this in the United States is called poor communication between educational institutions and parents who do not receive information about the problem due to their absence during the examination of the child (Guidelines, 2014; Colenbrander, 2018). In Ukraine today, this problem is primarily in the practical absence of comprehensive medical examinations of students in educational institutions, which increases the scale of the problem (Kostetska, 2012; Orlova \& Kostetska, 2014).

Studying puts a significant burden on the child's body and in case of non-compliance with hygienic requirements can provoke a number of "school diseases", one of which is a decrease in visual acuity (French et al., 2013; Jonas et al., 2016; Heiting, 2019).

Good vision is one of the most important functions of the human body, which allows a person to live fully, because it is vision that helps us get more than half of all information about the world around us. Therefore, the prevention of visual impairment should begin in childhood, which will maintain its severity for many years, and for this purpose can be used with great efficiency methods of therapeutic exercise (Kostetska \& Orlova, 2012).

\section{References}

Burnett, A. M., Yashadhana, A., Lee, L., Serova, N., Braina, D., Naidoo, K. (2018). Interventions to improve school-based eye-care services in low-and middle-income countries: a systematic review. Bulletin of the World Health Organization, 96:682-694D.

Chang, L. C., Liao, L. L., Chen, M. L., Niu, Y. Z, Hsieh, P. L. (2017). Strengthening teachers' abilities to implement a vision health program in Taiwanese schools. Health education research 32(5):437-447. 
Colenbrander, A. (2018). Vision Rehabilitation is Part of AMD Care. Vision, 2:4.

Cooper, J., Tkatchenko, A. V. (2018). A Review of Current Concepts of the Etiology and Treatment of Myopia. Eye \& Contact Lens, 44:231-247.

Datsenko, I. I., Denisyuk, O. B., Doloshitsky, S. L., Plastunov, B. A., Tolmachova, E. I., Shegedin, M. B. (2001) Zahalna hihiyena [General hygiene]. Lviv: Svit. [in Ukrainian]

Dmytriv, H. I., Freyik, N. V., Vladyka, O. T., Hlynyanyuk, N. V., Hrytsyuk, O. Ye., Dobryanska, N. M., Marotchak, R. M., Semanyuk, R. S., Skrypnyk, R. E., Tarasyuk, M. B., Fushchych, U. S. (2019). Nova ukrayinska shkola: poradnyk vykhovatelyu hrupy prodovzhenoho dnya $u$ zakladakh zahalnoyi serednoyi osvity [New Ukrainian school: a guide to the educator of the extended day group in general secondary education institutions]. Lviv: Svit. [in Ukrainian] Domashenko, N. Y. (2008). Faktory ryska formyrovanyia zrytelnykh rasstroistv u starsheklassnykov [Risk factors for the formation of visual disorders in high school students]. Journal of Ophthalmology, 2:40-43. [in Russian]

Duhina, L. (2016). Vplyv zasobiv fizychnoyi reabilitatsiyi na fizychnyy rozvytok ditey z vadamy zoru [Influence of means of physical rehabilitation on physical development of children with visual impairments]. Fìzična reabilitaciâ ta rekreacìjno-ozdorovčì tehnologï̈, 3:67-72. [in Ukrainian]

Formenti, D., Duca, M., Trecroci, A., Ansaldi, L., Bonfanti, L., Alberti, G., Iodice, P. (2019). Perceptual vision training in nonsport-specifc context: efect on performance skills and cognition in young females. Scientific Reports, 9:18761.

French, A. N., Morgan, I. G., Mitchell, P., Rose, K. A. (2013). Risk factors for incident myopia in Australian schoolchildren: the Sydney adolescent vascular and eye study. Ophthalmology, 120:2100-2108.

Guidelines for School-based Eye Health Programs: Information for policy-makers and planners on conducting vision screening as a component of school-based eye health, as part of an integrated school health programme. UNICEF. (2014). Convention on the Rights of the Child: A World of Difference: 25 CRC achievements. [Pежuм docmyny: https://www.unicef.org/crc/ index_73549.html].

He, M., Xiang, F., Zeng, Y., Mai, J., Chen, Q., Zhang, J., Smith, W., Rose, K., Morgan, I. G. (2015). Effect of time spent outdoors at school on the development of myopia among children in China: a randomized clinical trial. JAMA, 314:1142-1148.

Heiting, G. (2019). Vision problems of school-age children. [Режuм docmyny: https:// www.allaboutvision.com/en-gb/children-vision/vision-problems-schoolage/].

Holden, B. A., Fricke, T. R., Wilson, D. A., Jong, M., Naidoo, K. S., Sankaridurg, P., Wong, T. Y., Naduvilath, T. J., Resnikoff, S. (2016). Global prevalence of myopia and high myopia and temporal trends from 2000 through 2050. Ophthalmology, 123:1036-1042.

Ip, J. M., Saw, S. M., Rose, K. A., Morgan, I. G., Kifley, A., Wang, J. J., Mitchell, P. (2008). Role of near work in myopia: findings in a sample of Australian school children. Investigative Ophthalmology \& Visual Science, 49:2903-2910.

Jonas, J. B., Xu, L., Wang, Y. X., Bi, H. S., Wu, J. F., Jiang, W. J., Nangia, V., Sinha, A., Zhu, D., Tao, Y., Guo, Y., You, Q. S., Wu, L. J., Tao, L. X., Guo, X. H., Ohno-Matsui, K., Panda-Jonas, S. (2016). Education related parameters in high myopia: adults versus school children. PLoS One, 11:e0154554.

Kadochnikova, Yu. V., Khorkova, Zh. V. (2017). Fizicheskoye vospitaniye studentov, imeyushchikh zabolevaniya organov zreniya [Physical education of students with visual diseases]. Yekaterinburg. Izdatelstvo Uralskogo universiteta. [in Ukrainian] 
Kang, M.-T., Li, S.-M., Peng, X., Li, L., Ran, A., Meng, B., Sun, Y., Liu, L.-R., Li, H., Millodot, M., Wang, N. (2016). Chinese Eye Exercises and Myopia Development in School Age Children: A Nested Case-control Study. Scientific Reports, 6:28531.

Kostetska, A. O. (2012). Faktory ryzyku porushennya zorovykh funktsiy u shkolyariv m. Kyeva [Risk factors for visual impairment in schoolchildren of Kyiv]. Ukraine. Nation's Health, 2/3: 233-236. [in Ukrainian]

Kostetska, A. O., Orlova, N. M. (2012). Poshyrenist porushen zoru u shkolyariv ta problema yikh svoyechasnoho vyyavlennya [The prevalence of visual impairments in schoolchildren and the problem of their timely detection]. Zbirnyk naukovykh prats spivrobitnykiv NMAPO im. P.L. Shupyka, 21(2): 711-716. [in Ukrainian]

Kyzymenko, L. D., Snyadanko, I. I. (2009). Osnovy anatomiyi i fiziolohiyi lyudyny: teoretychnyy ta praktychnyy kurs. Lviv, Vydavnytstvo Natsionalnoho universytetu "Lvivska politekhnika». [in Ukrainian]

Lee, J.-W., Cho, H. G., Moon, B.-Y., Kim, S.-Y., Yu, D.-S. (2019). Effects of prolonged continuous computer gaming on physical and ocular symptoms and binocular vision functions in young healthy individuals. Peer J, 7:7050.

Li, S. M., Li, S. Y., Kang, M. T., Zhou, Y., Liu, L. R., Li, H., Wang, Y. P., Zhan, S. Y., Gopinath, B., Mitchell, P., Wang, N. (2015). Near work related parameters and myopia in Chinese children: the Anyang Childhood Eye Study. PLoS One, 10:e0134514.

Milyukova, I. V., Yevdokimova, T. A. (2003). Polnaya entsiklopediya lechebnoy gimnastiki [Complete encyclopedia of therapeutic gymnastics]. SPb: Sova; M: Izdatelstvo Eksmo, 2003. 512 s. [in Russian]

Moiseyenko, R. O., Holubchykov, M. V., Mykhalchuk, V. M., Rykov, S. O. (2018). Oftalmolohichna dopomoha $v$ Ukrayini za 2014-2017 roky: analitychnostatystychnyy dovidnyk. Kropyvnytskii: POLIUM, [in Ukrainian]

Orlova, N. M., Kostetska, A. A. (2014). Povedinkovi chynnyky ryzyku rozvytku patolohiyi orhana zoru u miskykh shkolyariv. Ukr. med. chasopys [Behavioral risk factors for the development of pathology of the visual organ in urban schoolchildren]. Ukrainian Medical Journal, 1: 137-139. [in Ukrainian]

Orlova, N. M., Kostetska, A. O. (2014). Stan oftalmolohichnoho zdorovya shkolyariv ta orhanizatsiyna tekhnolohiya yoho medyko-sotsialnoho monitorynhu [The state of ophthalmological health of schoolchildren and organizational technology of its medical and social monitoring]. Ukraine. Nation's Health, 1:7-12. [in Ukrainian]

Rose, K. A., Morgan, I. G., Ip, J., Kifley, A., Huynh, S., Smith, W., Mitchell, P. (2008). Outdoor activity reduces the prevalence of myopia in children. Ophthalmology, 115:1279-1285.

Ruban, L. A. (2016). Metody korektsiyi miopiyi fizychnymy vpravamy [Methods of correction of myopia by physical exercises]. Visnik Chernigivskogo Nacionalnogo Pedagogichnogo Universitetu. Seriya: Pedagogichni Nauki. Fizichne Vihovannya Ta Sport, 2:193-197. [in Ukrainian] Rykov, S. O., Yaremenko, N. M., Kharchenko, L. B., Lishchyshyna, O. M., Rubtsova, YE. I., Shylkina, O. O. (2019). Kompleksne obstezhennya oka ta zoru klinichna nastanova, zasnovana na dokazakh [Complex examination of the eye and vision clinical guidelines based on evidence]. Derzhavnyy ekspertnyy tsentr MOZ Ukrayiny. [Режим достуny: https://www.dec.gov. ua/wp-content/uploads/2019/11/2019_09_20_kn_kompl_obst_okazory.pdf]. [in Ukrainian] Tsybulska, T. Ye. (2019). Funktsionalni, biometrychni ta biomékhanichni zminy parametriv oka pry miopiyi u ditey: osoblyvosti likuvannya ta optychnoyi korektsiyi [Functional, biometric and biomechanical changes of eye parameters in myopia in children: features of treatment and optical correction]. Dissertation Dr. Med. Sciences, 14.01.18-Ophthalmology, 222 - Medicine. 
Zaporizhzhya State Medical University, P.L. Shupyk National Medical Academy of Postgraduate Education. Zaporizhzhia. [in Ukrainian]

Tsybulska, T. Ye., Pashkova, O. Ye. (2018). Analiz faktoriv, shcho vplyvayut na prohresuvannya nabutoyi miopiyi $u$ ditey [Analysis of factors influencing the progression of acquired myopia in children]. Zbirnyk naukovych prats spivrobitnykiv NMAPO im. P. L. Shupika, 30:271-282. [in Ukrainian]

Tymchyk, O. (2019). Fizychna reabilitatsiya ditey shkil'noho viku z miopiyeyu I-III stupenyu [Physical rehabilitation of school-age children with myopia of I-III degree]. Sport Science and Human Health, 1(2):107-119. [in Ukrainian]

Wu, P. C., Tsai, C. L., Wu, H. L., Yang, Y.H., Kuo, H. K. (2013). Outdoor activity during class recess reduces myopia onset and progression in school children. Ophthalmology, 120:1080-1085. 